\title{
TIPOGRAFI ARAB PEGON DALAM PRAKTIK BERBAHASA MADURA DI TENGAH DINAMIKA KEBUDAYAAN YANG DIUSUNG HURUF LATIN
}

\author{
Naufan Noordyanto \\ Mahasiswa Magister Penciptaan dan Pengkajian Seni, Minat Studi Desain Komunikasi Visual \\ Program Pascasarjana Institut Seni Indonesia Yogyakarta \\ noordbita@gmail.com
}

\begin{abstract}
Arabic pegon script or pegon script is the term of a few Hijaiyah/Arabic letters that is generally modified and used to write in Malay and Javanese. In Madura, East Java, Pegon script is used for the writing in the language of Madura and other languages, such as Java language. Unfortunately, practices of writing with Arabic typography Pegon in everyday life today, especially in the area of Madura, still as though vague, because the practice of typography around the world still dominated by "regimes" in Latin script. Pegon script as the focus of typography, is seen as an instrument to realize the visual language. Visuality of language in the form of Pegon script involving practices of language (Madura language). Pegon script actually is the result of "hard work" of efforts to "reconcile" the letter of the culture that was at first considered foreign (Arab-Islamic) with the local culture, especially the language of the local/indigenous (vernacular language). Now, practices of Pegon script can be said of a shift in usage habits. The practice Pegon script initially suspected rolling as a means of spread and transmission of Islamic knowledge, then it took place as an instrument of islamic education (literacy) in islamic students (santri) society, then it also turned increasingly popular and wider scope in the practice for the daily communications. However, in this era of Latin script, pegon script can be said to be marginalized in the corner of the specific socio-cultural environment, and has failed to return "to play" in the global arena, and tend to be replaced with Latin letters that dominate the world of typography practices.
\end{abstract}

Keywords: pegon, scripts, letter, Latin, Arabic, Madura, Islam, culture

\section{PENDAHULUAN}

\section{Latar Belakang Masalah}

Jika umumnya masyarakat mengetahui penggunaan Arab Pegon untuk menuliskan kata dalam bahasa Melayu (Indonesia lama) dan Jawa, maka di Madura, Jawa Timur, huruf Arab Pegon juga berperan penting dalam perkembangan budaya literasi dan intelektualitas masyarakat Madura. Arab Pegon merupakan sebutan untuk huruf Hijaiyah/Arab yang digunakan untuk menulis bahasa Melayu dan Jawa (dahulu Jawa Kuno) (Sanusi, 2010: 65). Orang Melayu seringkali menyebutnya dengan "tulisan Jawi", "huruf Jawi", atau "Arab Melayu" (Pemkab Pamekasan dan FIB UGM, 2010: 37). Bedanya dengan huruf Hijaiyah original yaitu merujuk pada typeface (rupa huruf) huruf Arab yang digubah dengan mengadakomodasi huruf dan pelafalan bahasa lokal, misalnya Melayu, Jawa, atau Madura. 
Dalam tulisan Hisyam (2006: 490-491) tentang Arab Pegon, khususnya untuk bahasa Jawa, Arab Pegon merupakan hasil mengasimilasikan fonem huruf Hijaiyah ke dalam bahasa lokal. Dalam sumber yang sama pula, istilah pegon secara etimologi berasal dari kata bahasa Jawa "pego" yang berarti "tidak biasa" yang merujuk pada beberapa huruf gubahan dari huruf Hijaiyah tersebut.

Di Madura, Arab Pegon dipakai untuk menuliskan bahasa Madura maupun bahasa lainnya, misalnya bahasa Jawa. Dalam keseharian, secara pribadi penulis menyebutnya "Arab Madhurâ'ân" (terminologi Madura, baca: Arab Madhureen) yaitu sebutan khusus untuk huruf Arab (bergaya/corak) bahasa Madura. Lantaran berdasarkan pengamatan penulis, terkadang penyebutan istilah "pegon" bisa dibilang tidak terlalu familiar di beberapa orang Madura (khususnya masyarakat umum), namun jika disebutkan dengan istilah Arab Madhurà'àn, aksara yang dimaksud bisa dipahami.

\begin{tabular}{|c|c|c|c|c|c|}
\hline$\tau^{h a}$ & $ج^{j i m}$ & $\dot{\Theta}_{t i a}$ & $ت_{t a}$ & $\varphi b a$ & أ alif \\
\hline$\jmath \quad r a$ & ذ dzal & $\dot{\jmath}$ dha & $د d a l$ & $\dot{乙}^{k h a}$ & ج $c a$ \\
\hline b tho & ض dhad & $\boldsymbol{\omega}$ shad & ش syin & س sin & j $z a$ \\
\hline ف pa & $\dot{\varepsilon} n g a$ & $\dot{\varepsilon}$ ghain & $\varepsilon^{\text {ain }}$ & ظdho & bta \\
\hline مim & لlam & گ ga & $\varsigma_{k a f}$ & ق qaf & ثेpa \\
\hline ي nya & ي ya & s hamzah & $\Delta b a$ & g wau & ن nun \\
\hline
\end{tabular}

Gambar 1 Tabel daftar huruf Arab Pegon dalam deretan huruf Hijaiyah original

Sumber: koleksi penulis
Menulis dengan Arab Pegon berbahasa Madura berarti menuliskan huruf hijaiyah yang telah dimodifikasi tersebut dengan ejaan kata dan pelafalan bahasa Madura. Bentuk modifikasi rupa huruf Arab menjadi huruf Pegon menghasilkan tujuh karakter huruf (simbol fonem) baru dan teralienasi dari huruf Hijaiyah original, di antaranya: cha, dha, tha, nga, pa, ga, nya, (Hisyam, 2006: 490). Karakter huruf "cha" dimodifikasi dengan menambahkan dua titik pada huruf "jim"; huruf "dha" dimodifikasi dengan menambahkan tiga titik pada huruf "dal"; huruf "tha" dimodifikasi dengan menambahkan tiga titik pada huruf "tho"; huruf " $n g a$ " dimodifikasi dengan menambahkan tiga titik pada huruf "ain"; huruf " $p a$ " dimodifikasi dengan menambahkan dua titik pada huruf " $f a$ "; huruf " $g a$ " dimodifikasi dengan menambahkan satu titik pada huruf "kaf"; huruf "nya" dimodifikasi dengan menambahkan tiga titik pada huruf " $y a$ "; (lihat gambar 1). Teknik penulisan sama dengan penulisan huruf Arab lazimnya, serta ditulis dan dibaca dari kanan ke kiri.

Sayangnya, praktik-praktik tipografi Arab Pegon di keseharian saat ini, khususnya di lingkup Madura, masih seolah-olah samar (tidak nampak), mengingat praktik tipografi dunia masih dikuasai "rezim" huruf Latin. 
Praktisi tipografi Arab Pegon dalam penggunaan dan kreativitasnya tentunya dipengaruhi paradigma dari konteks sosial budaya yang mempengaruhi. Untuk memahami fenomena tersebut, studi ini bermaksud menelusuri pelbagai praktik tipografi Arab Pegon dihubungkan dengan konteks sosial budaya yang melatarbelakanginya dalam lingkup masyarakat Madura, Propinsi Jawa Timur.

\section{Rumusan Masalah}

Bagaimanakah fungsi dan perkembangan praktik tipografi Arab Pegon berbahasa Madura di Madura dan di tengah dinamika kebudayaan yang diusung huruf Latin?

\section{Batasan dan Tujuan Penelitian}

Tulisan ini sebagai hasil kajian tersebut, berupaya mengurai fungsi dan dinamika praktik tipografi tersebut dalam kadar yang "ringan". Penelusuran praktik-praktik tipografi Arab Pegon di masa lampau dan masa sekarang dikaji dalam kerangka Desain Komunikasi Visual (DKV). Lebih tepatnya dalam perspektif tipografi atau ilmu tentang huruf. Huruf Arab Pegon sebagai perhatian tipografi, dipandang sebagai instumen untuk mewujudkan bahasa secara visual. Visualitas bahasa dalam bentuk huruf Arab Pegon melibatkan praktik-praktik berbahasa (Madura). Bahasa dianggap sebagai modus dan motif dalam praktik tipografi Arab Pegon, di mana praktik tipografi tersebut mampu berkontribusi dalam interaksi sosial.

Penelitian tentang huruf Pegon umumnya terkait daerahnya di Jawa serta perkembangan di kalangan santri di Jawa, misalnya yang ditemukan pada tulisan Muhamad Hisyam berjudul "Pegon Script, Identity and the Change of Santri Society" dalam buku Archaelogy: Indonesian Perspective, terbitan LIPI Press, Jakarta, 2006. Sementara penelitian dan kajian khusus tentang praktik dan perkembangan huruf Pegon di Madura sangat minim. Sekelumit penelitian tentang bukti praktik literasi tipografi Pegon, serta dugaan asal usul Pegon khususnya di kabupaten Pamekasan, Madura, hanya dibahas sepintas dan singkat sekitar dua halaman kurang (halaman 37-39) dan (halaman 177-179) dalam buku Ensiklopedi Pamekasan: Alam, Masyarakat, dan Budaya yang ditulis Pemerintah Kabupaten (Pemkab) Pamekasan dan Fakultas Ilmu Budaya Universitas Gadjah Mada (FIB UGM) Yogyakarta pada 2010. Sementara kitab-kitab keagamaan di kalangan pesantren sudah umum yang memakai huruf Pegon berbahasa Madura, namun bukan membahas praktik tipografi Pegon berbahasa Madura itu sendiri. Kendati demikian, perkembangan praktik tipografi Pegon di kalangan santri inilah 
kemudian menjadi referensi penting untuk menelusuri perkembangannya lebih lanjut melalui penelitian ini.

\section{Metode dan Pendekatan Penelitian}

Selain kajian pustaka, dalam rangka menelusuri perkembangan praktik dan wacana tipografi Arab Pegon dalam konteks dewasa ini, penulis berupaya mendapatkan sumber lisan dengan memilih beberapa informan, terutama pemuda lulusan pesantren atau madrasah yang dianggap mewakili generasi terkini dan yang pernah mengalami/menjalani kondisi lingkungan pesantren, serta pernah menggeluti praktik tipografi tersebut.

Kajian ini dilakukan dengan analisis kualitatif deksriptif. Sebelumnya, perlu dipahami bahwa kajian ini bersifat multi paradigma. Artinya dalam upaya analisis interpretatif, penulis tidak hanya memposisikan diri di dalam area obyek penelitian atau membatasi perhatian pada ranah DKV terkait praktik tipografi Arab Pegon di lingkungan Madura. Tetapi juga memasukan nilai-nilai subyektifitas dalam format analitis atas fakta-fakta yang dikaji. Maka, sebagai pendekatan, penulis meminjam kode-kode hermeneutika "langue" dan "discourse" dari Paul Ricoeur dalam studi analisis kualitatif-interpretatif terkait praktik tipografi Arab Pegon yang digunakan dalam menuliskan bahasa Madura dan wacana yang terkait dengannya, khususnya dalam konteks sosio-kultural.

Istilah langue (language: bahasa) merujuk pada bahasa secara umum, yakni tanda-tanda linguistik yang biasanya bersifat kolektif dan sistematik, atau bisa dibilang merujuk pada kondisi tekstual (Ricoeur, 2012: 21-27 dan 32). Menurut Ricoeur (2012: 52), “memaknai 'teks' adalah apa yang diinginkan (dilakukan) oleh pengarang, yang mendudukan penafsir untuk berupaya memahami kandungan proporsional/obyektif”. Kaitannya dengan penelitian, praktik tipografi Arab Pegon di lingkungan Madura diperlakukan sebagai "teks" yang bisa "dibaca” secara "gramatikal" untuk dipandang dari perspektif perawat tradisi (pencetus secara warisan kebiasaan) yang ada dan berlangsung, maka di sinilah yang dimaksud penulis sebagai fokus obyektif penelitian.

Sedangkan discourse (wacana) menurut Ricoeur (2012: 17-18) dimaknai sebagai tata bahasa yang dibentuk dari kalimat sebagai satuan partikular pembentuk sistemnya. Namun, untuk membedakannya dengan bahasa, lokus wacana menekankan pada dialektika dua kutub, yaitu wacana sebagai peristiwa dan makna (meaning). 
Fashri (2014: 34-36) me-resume tentang dialektika dua kutub wacana tersebut. Pertama, wacana sebagai peristiwa: "wacana dalam ujaran kalimat bukan hanya sebagai rangkaian kata-kata yang bersifat gramatikal, tapi terkait tempat dan waktu (bersifat historis), memiliki subyek, menunjuk pada sesuatu (reference), dan berlangsung pada praktik komunikasi”. Relevansinya dengan karya yang diulas penulis, bahwa tipografi Arab Pegon yang digunakan untuk menuliskan Madura dianggap sebagai "teks" yang tidak hanya bisa "dibaca" secara "gramatikal", tapi harus dihubungkan dengan peristiwa dan gejala sosio-kultural yang melingkupinya. Sebab berbicara tentang praktik tipografi Arab Pegon di lingkungan Madura itu sendiri, sekaligus juga wacana yang muncul dari fenomena praktiknya.

Kedua, wacana sebagai makna (meaning): "makna muncul dari proses pemahaman atas wacana ketika direalisasikan menjadi peristiwa, atau wacana tidak hanya dianggap sebagai peristiwa saja, namun dimengerti dan dipahami maknanya”. Dengan kata lain, di dalam wacanalah (bukan bahasa), makna ditemukan, karena wacana sebagai peristiwa bertranformasi (dipahami) sebagai makna. Upaya menafsirkan makna dari konteksnya (pendekatan) wacana sosiokultural inilah menekankan sisi-sisi subyektif penulis. Maka jelas, dalam studi terkait praktik tipografi Arab Pegon di lingkungan Madura ditelusuri maknanya melalui penafsiran atas wacana sosio-kultural yang melingkupinya.

Mengingat pada teks (selanjutnya disebut huruf/tipografi Arab Pegon yang dimaksud) terjadi problem "distansiasi”, yaitu “jarak (kejadian spasial atau jarak temporal) yang terjadi karena kesenjangan antara dunia perawat tradisi tipografi yang "dibaca" oleh penafsir dengan dunia penyaji tipografi. Sejalan dengan distansiasi, juga muncul "apropriasi" yaitu "menjadikan apa yang asing menjadi milik penafsir" (Ricoeur, 2012: 95). Maka sebagai konsekuensi hermeneutika, adanya distansiasi, karya (tipografi) menjadi otonom atau dapat lepas dari horizon penyaji (perawat tradisi). Sehingga penulis dapat mengambil jarak (distansiasi) dari sisi obyektif praktik tipografi yang dimaksud perawat tradisi tipografi, tetapi juga memungkinkan untuk melakukan apropriasi atau penelusuran makna (kontekstual) secara mandiri (subyektif) dan kreatif melalui penafsiran atas wacana sosio-kultural yang melingkupinya (Ricoeur, 2012: 95 dan Fashri, 2014: 36-38). Baik distansiasi maupun apropriasi merupakan instrumen penting yang dipakai dalam hermeneutik.

Sebagai pendukung kajian terhadap wacana, penulis juga memakai pelbagai teori 
pendukung lain kaitannya dengan praktik sosio-kultural, agar menjadi dasar analisis dan terbentuk jalinan makna yang bersambung. Dengan demikian, penulis selaku penafsir tidak hanya berusaha menelusuri makna dan menginterpretasi tradisi praktik tipografi Arab Pegon di lingkungan Madura (sebagai “teks”). Justru penulis berupaya manjaga keterbukaan karya atas studi beragam interpretasi lain dengan konteks dan pendekatan yang berbeda-beda, serta secara mandiri memberikan makna (meaning) atas fenomena sosio-kultural tersebut. Upaya memahami "teks" dan "konteks" ini kemudian dianalisis terintegrasi.

\section{HASIL PENELITIAN DAN PEMBAHASAN}

Arab Pegon di Madura dalam pendekatan kultur-historis (masa awal persebaran Islam)

Pendekatan kultur-historis sangat membantu dalam memahami praktik-praktik dan wacana tipografi Arab Pegon di Madura, khususnya di masa lampau hingga masa kini. Perbincangan tentang praktik-praktik tipografi Arab Pegon di Madura tidak terlepas dari keberhasilan penetrasi kebudayaan Islam pada masyarakat etnik Madura. Meskipun tidak diketahui secara pasti, distribusi penggunaan huruf Arab Pegon di Madura diperkirakan karena pengaruh islamisasi dari Jawa. Mengingat perkembangan awal Arab Pegon sendiri berasal dari Jawa, menurut Hisyam (2006: 491), penggunaan, diaspora, perkembangan Arab Pegon tidak terlepas dari peran kelompok masyarakat Jawa yang terpengaruh kuat oleh kebudayaan Islam yang berasal dari Arab. Karena kesulitan menerjemahkan katakata dan konsep-konsep Islam dan Arab secara spesifik ke dalam bahasa Jawa, akhirnya diupayakan mengadopsi bunyi/fonem asli dari bahasa Jawa yang ditulis dengan Arab Pegon. Perkembangan Arab Pegon di Jawa diduga telah berlangsung sejak abad XIII, yaitu sejak masuknya pengaruh Islam di Jawa (Pemkab Pamekasan dan FIB UGM, 2010: 38). Sementara huruf Hijaiyah sendiri mulai digunakan seiring berdirinya kerajaankerajaan Islam dan persebaran Islam di Nusantara sejak abad VIII (Sanusi, 2010: 65).

Praktik tipografi Arab Pegon dalam tradisi baca tulis di Madura diduga berhubungan erat dengan aktivitas syiar Islam oleh ulama-ulama Jawa. Masa awal islamisasi di Madura berlangsung karena peran salah seorang wali sanga atau sembilan wali penyebar Islam di Nusantara, yang dikenal sebagai Sunan Giri dari Gresik, Jawa Timur, dan merupakan murid dari Sunan Ampel Surabaya, serta peran para saudagar Islam dari Gujarat yang singgah di pelabuhan Madura, salah satunya di Kalianget, kabupaten Sumenep (Abdurrachman, 1971: 16-17). 
Disebutkan pula, seorang penyiar Islam datang ke Sumenep, yang kemudian kesohor dengan sebutan Sunan Padusan. Dalam Babad Madura alih bahasa Madura karangan Werdisastra (1996: 123-124) disebutkan bahwa Sunan Padusan adalah keturunan Sunan Ampel dan Maulana Malik Ibrahim. Dalam Abdurrachman (1971: 16), sebutan "Padusan" disematkan masyarakat lantaran kebiasaan Sunan tersebut yang sering memandikan (edus: mandi) orang yang masuk Islam atau dipandang mampu untuk menjalankan syariat (aturan dan hukum Islam). Melihat Islam semakin diterima masyarakat luas, khususnya rakyat Sumenep, Raden Jokotole atau Arya Jaranpanole yang bergelar Pangeran Secadiningrat III (14151460), penguasa Sumenep (Madura Timur) di bawah kekuasaan Majapahit masa itu, menyatakan tertarik dan memeluk Islam, bahkan Sunan Padusan dijadikannya menantu untuk putrinya.

Dengan semakin meluas dan berkembangnya penetrasi Islam di Madura, maka kebudayaan Arab ikut terbawa sampai ke pelosok Madura, termasuk seni pertunjukan bercorak Arab seperti hadrah, zamrah, dan gambus, menjadi kesenian rakyat atau menjadi bagian kebudayaan Madura dengan corak tersendiri (Departemen Pendidikan dan Kebudayaan R.I., 1979: 101 dan Moelyono, dkk., 1984: 42). Artinya, pengaruh kebudayaan Islam dan Arab memberi ruang yang kondusif untuk lahirnya kecenderungan adaptasi kesenian "baru" khususnya dalam konteks seni pertunjukan di Madura, termasuk pelafalannya dengan katakata dan lirik Arab.

Imbasnya, terlepas dari aspek instrumental dan musiknya, baik untuk kepentingan religius maupun profan, yaitu sekaligus memberikan ruang transmisi penggunaan bahasa Arab baik lisan maupun tertulis dengan huruf Hijaiyah dalam lirik-lirik pujian Islami seni pertunjukan tersebut, misal salah satunya bersumber dari kitab Barzanji sebagaimana yang penulis ketahui, dan sama halnya yang pernah dicatat oleh Bouvier (2002: 84 dan 86). Sehingga bisa dimungkinkan tradisi tulis huruf Arab untuk pembelajaran kesenian tersebut telah berlangsung, selain pembelajaran tentang syiar dan hukum Islam sendiri. Mengingat kesenian-kesenian tersebut umumnya dilafalkan dengan (dominasi) bahasa Arab untuk urusan religius maupun profan (terkadang campur berbagai bahasa, termasuk bahasa lokal), meskipun belum bisa dipastikan bahwa masyarakat berkomunikasi secara tertulis dengan huruf Arab Pegon.

Di samping itu, semakin merosotnya Majapahit (Trowulan, Mojokerto) serta pengaruh kesultanan-kesultanan Pesisir Utara 
bertolak dari kesultanan Demak yang makin kuat, pengaruh kebudayaan Islam Jawa semakin jelas sejak Sumenep (Madura Timur) berada di bawah pemerintahan Raden Tumenggung Kanduruan, Putra Raden Patah (Sultan Demak) menjabat sebagai adipati Sumenep di bawah kekuasaan kesultanan Demak (1559-1562). Pasca pemerintahan kesultanan Demak, Madura berada di bawah kekuasaan Mataram Islam (1568-1672), kurun pemerintahan dari Sutawijaya hingga Amangkurat II (Departemen Pendidikan dan Kebudayaan R.I., 1979: 122). Sehingga Madura sebagai wilayah "taklukan" bagian pemerintahan kerajaan Islam tersebut, tentunya mengikuti dan berorientasi pada pusat pemerintahan di Jawa. Bahkan menurut Pigeaud (1967, I:136) dalam Bouvier (2002: 22), "pada abad XVI-XVII, daerah Madura di bawah pimpinan sultan-sultan yang mungkin keturunan campuran Jawa-Madura, kadangkadang memainkan peran penting dalam urusan politik Jawa”.

Sementara, dalam Sanusi (2010: 63-65) sekitar abad XVI mulai berkembang sastra Melayu dan Jawa Islam, ketika Islam menstimulan Jawa dan membangun pondasi politik sebagai alat pemersatu kerajaan Banten, Cirebon, Demak, bahkan Mataram. Tradisi tulis kerajaan Islam Nusantara menghendaki penulisan dengan huruf Arab Pegon, karena kuatnya pengaruh Arab sebagai simbol-simbol Islam. Beberapa bukti naskah diketahui ditulis sekitar abad XVI-XVII dari kerajaan Demak, Banten, Mataram, Surakarta Pakualaman, Mangkunegara, Cirebon, Melayu, Lambi, Mempawah, Makassar, Maluku.

Dari fenomena tersebut dapat dimengerti bahwa selain agama Islam itu sendiri, praktik tipografi Arab Pegon sebagai produk akulturasi kebudayaan menjadi instrumen legitimasi "persatuan" untuk membentuk masyarakat pribumi berkebudayaan Islam di Nusantara sebagai komunitas tersendiri membedakan kebudayaan lain yang hidup di sekitarnya, sekaligus meningkatkan aware terhadap kebudayaan Islam dan Arab itu sendiri. Rupa (visual) huruf (typeface) Arab Pegon dikehendaki semakin memasyarakat dan populer, agar masyarakat dapat belajar sekaligus menulis dan membaca dengan huruf tersebut. Sebab, jika tradisi tulis didominasi dengan tuntutan penggunaan huruf Arab Pegon, maka generasi pembelajar selanjutnya secara tradisional akan mengikut generasi sebelumnya untuk belajar dan membiasakan diri dengan huruf tersebut. Kecenderungan ini berpengaruh pada familiarity huruf sehingga masyarakat semakin akrab/familiar yang tentunya dapat meningkatkan daya kenal/keterbacaan (legibility) huruf. 


\section{Arab Pegon sebagai identitas santri dalam pendekatan kultur-historis}

Kehadiran Islam di tanah Jawa menyebabkan pertemuan dua kebudayaan, yaitu kebudayaan Islam (Arab) dan Jawa. Meskipun Jawa di bawah pengaruh Islam, penetrasi Islam tidak menyentuh seluruh lapisan masyarakat dan kebudayaan. Pengaruh kebudayaan Islam yang kuat dan semakin diterima masyarakat luas sekitar abad XV-XVI, menyebabkan masyarakat Jawa Islam membentuk identitas tersendiri. Pada perkembangannya, pengaruh islam kemudian membentuk kelompok masyarakat dengan segmentasi tertentu yang terpengaruh relatif kuat oleh Islam, namun tidak meninggalkan kebudayaan Jawanya, yaitu kelompok masyarakat santri. $\mathrm{Hal}$ tersebut membedakan dari corak masyarakat Jawa yang masih memegang teguh tradisi keagamaan pra Islam atau disebut masyarakat kejawen atau kelompok Jawa Islam yang masih mempertahankan tradisi pra Islam (Islam sinkretis) yang disebut Islam kejawen atau abangan. Oleh karena itu, menurut Hisyam (2006: 491-492), masyarakat santri lebih memilih, menggunakan, dan mempopulerkan huruf Arab Pegon sebagai simbol kebudayaan Islam yang kuat mempengaruhinya.

Begitu pula di Madura, mengingat terdapat asumsi terkait persebaran Arab Pegon ke Madura akibat islamisasi dari Jawa dan perkembangan huruf Arab Pegon itu sendiri dari Jawa dan disebarluaskan masyarakat santri, maka dimungkinkan pula bahwa praktik penggunaan Arab Pegon di Madura juga tidak dapat dipisahkan dengan aktivitas penyelenggaraan pendidikan di lingkungan pesantren (Pemkab Pamekasan dan FIB UGM, 2010: 37). Penulis setuju dengan asumsi tersebut, mengingat tradisi menulis dengan huruf Arab Pegon masih berlangsung hingga saat ini di lingkungan sekolah Islam bercorak Nusantara tersebut. Menurut informasi yang didapatkan dari salah seorang guru agama dan alumni pesantren, Mas'udi Eko Diansyah, terungkap bahwa praktik tipografi di dalam pesantren, yaitu digunakan dalam proses belajar dan mengajar, terutama penerjemahan berbagai kitab berbahasa dan beraksara Arab. Tipografi Arab Pegon juga digunakan untuk komunikasi tertulis berbahasa Madura antar civitas pesantren, misalnya melalui memo tertulis dari kiai atau ustadz terhadap sesamanya, maupun terhadap santri untuk menyampaikan pesan tertentu. Dari sini, diketahui bahwa bahasa dianggap sebagai modus dan motif dalam praktik tipografi Arab Pegon, di mana praktik tipografi tersebut mampu berkontribusi dalam interaksi sosial.

Selain itu, bahasa Madura sendiri, khususnya bahasa tingkat halus (èngghibhunten), juga umumnya menjadi bahasa 
komunikasi pengantar keseharian baik kepada pihak yang lebih tua atau sepantaran (baik antar kiyai, kiyai dan santri, sesama santri, atau warga pesantren dengan warga masyarakat umum), maupun bahasa pengantar pendidikan di lingkungan pesantren, baik pesantren di Pulau Madura maupun di luar Madura (daerah "Tapal Kuda” Jawa Timur: Lumajang, Pasuruan, Probolinggo, Jember, dll). Dengan kata lain, dalam konteks perawatan tradisi pesantren merupakan "benteng pertahanan" yang merawat, menjaga, dan melindungi tumbuh suburnya tradisi baca tulis huruf Arab Pegon dengan bahasa Madura sekaligus pelestarian bahasa Madura itu sendiri sebagai bahasa ibu.

Menurut Mas'udi, praktik tipografi Arab Pegon untuk menuliskan terjemahan kitab dalam bahasa Madura adalah berdasarkan tradisi penerus sebelumnya, terutama oleh perawat kebijakan tradisi dalam pesantren yaitu para kiai atau guru yang memberikan pengajaran. Diketahui para santri saat itu tidak mengerti motif penggunaan tipografi Arab Pegon di pembelajaran, lebih-lebih dengan bahasa Madura. Hal ini besar kemungkinan, santri-santri hanya patuh dan tunduk pada gurunya sebagai junjungan yang disegani. Sementara kalangan guru atau kiai tersebut adalah asli etnis Madura. Meskipun pesantren yang ia masuki berada di kalangan tanah Jawa, dan santri-santri tidak hanya dari Madura, pengajarannya tetap menggunakan pengantar bahasa Madura. Namun, berdasarkan pengetahuannya pula, kebijakan terkait penggunaan bahasa demikian bergantung pada otoritas pesantren yang berbeda-beda tiap pesantren, terutama dalam penggunaan bahasa. Dalam konteks ini, penulis melihat bahwa kondisi ini mempraktikan praktik dominasi dan minoritas, dengan kiai yang memiliki kekuatan politis yang mendominasi secara otonom dan memberikan pengaruh dan diaspora kebudayaan Arab dan Madura kepada pihak minoritas santri.

Apalagi, di Madura sendiri, misalnya di Pamekasan, telah berdiri beberapa pondok pesantren sejak abad XVI yang masih eksis hingga sekarang. Di antaranya Pondok Pesantren (PP) Miftahul Ulum Bèrè Lèkè di Kampung Toronan, Desa Larangan Badung, Kecamatan Palengaan, yang didirikan Syekh Abdurrahman sejak 1500-an M merupakan pondok pesantren tertua di Pamekasan, dan PP Sumberanyar Az-Zubair di Desa Larangan Tokol, kecamatan Tlanakan, Pamekasan, yang didirikan oleh Kiyai Zubair sekitar 1515 M (Pemkab Pamekasan dan FIB UGM, 2010: 271 dan 279). Bahkan Syeh Abdurrahman tersebut pernah menjadi santri di Ponpes Candenah, Kwanyar, Bangkalan (Madura Barat), yang artinya besar kemungkinan sebelum Ponpes 
Miftahul Ulum Bèrè Lèkè didirikan di Pamekasan, tradisi pendidikan pesantren sudah hadir di Madura (Pemkab Pamekasan dan FIB UGM, 2010: 279). Dengan begitu, menurut penulis, tidak tertutup kemungkinan budaya literasi dan sosialisasi rupa huruf Arab Pegon melalui kegiatan belajar mengajar maupun kajian kitab-kitab di kalangan santri Madura sudah hadir sejak Abad XV-XVI.

Sama halnya di Jawa, huruf Arab Pegon lebih familiar dan populer di kalangan pesantren di Madura atau pesantren di Jawa (khususnya Jawa Timur) yang bercorak Madura, terutama dipakai untuk menuliskan komentar, penjelasan, atau keterangan tambahan tulisan pada kètab konèng (terminologi Madura) atau kitab kuning. Penyebutan "kuning" merujuk pada warna kertasnya yang memang khas berwarna kuning. Kitab kuning biasanya ditulis dengan huruf Hijaiyah berbahasa Arab tanpa harakat atau tanda pelafalan bunyi pada huruf, sehingga orang Madura menyebutnya kètab ghundul atau kitab gundul. Begitu juga penulisan Arab Pegon umumnya tanpa harakat, sehingga seringkali sebut disebut Arab ghundul atau Arab gundul, meskipun ada praktik-praktik penulisan Arab Pegon dengan harakat dengan tujuan untuk memudahkan pembaca, terutama bagi pemula.
Materi kitab kuning biasanya menjadi bahan ajaran dan rujukan para santri dalam mengkaji hal-hal yang berkaitan dengan masalah keagamaan Islam, fiqih (hukumhukum Islam), tauhid (ilmu mengesakan Tuhan), tata bahasa Arab (nahwu), ushuluddin, aqidah (keyakinan), hadits (sumber hukum Islam dari Nabi Muhammad), tafsir Quran, dan lain-lain. Semakin banyaknya kitab karangan ulama-ulama Jawa maupun terjemahan kitab-kitab ulama Timur Tengah oleh ulama Madura dengan huruf Arab Pegon berbahasa Madura yang dipelajari para santri, juga liner dengan diaspora dan penggunaan tipografi Arab Pegon (lihat gambar 2).

Penguasaan materi kitab kuning atau kitab-kitab lainnya umumnya merupakan skill wajib dan menjadi corak klasik tradisi pesantren salaf atau tradisional. Karakteristik pembelajaran dan kajian kitab kuning di kalangan pesantren salaf adalah dengan metode sorogan dan bandongan. Berdasarkan Pemkab Pamekasan dan FIB UGM (2010: 272), metode sorogan merupakan "metode menyimak, mendengarkan, memperhatikan baik-baik, meninjau, memeriksa, sekaligus mempelajari dengan tetliti, perihal yang disampaikan guru atau kiyai terkait konten materi kitab kuning, kemudian dituliskan oleh santri pada kitab kuning masing-masing”. 
Sedangkan bandongan merupakan "metode pembelajaran dengan cara santri meniru pembacaan materi oleh guru secara bersamasama melalui kitab yang disimaknya". Di Madura, misalnya di Pamekasan, metode sorogan dan bandongan sejak awal dipakai oleh PP Sumberanyar di Desa Larangan Tokol Pamekasan, yang kemudian bertransformasi mengikuti kurikulum formal sejak 1950-an, begitu juga PP Darul Ulum Banyuanyar, kecamatan Palengaan, Pamekasan sejak didirikan $1785 \mathrm{M}$ meskipun sekarang sudah modern, dan ponpes-ponpes lainnya (Pemkab Pamekasan dan FIB UGM, 2010: 276 dan 281).
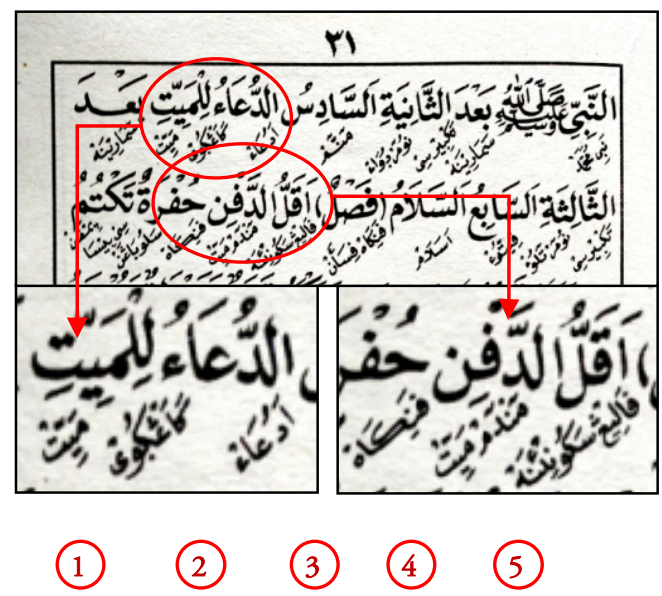

Gambar 2 Potongan tulisan berbahasa Arab dalam kitab berjudul Safinatun Najah bab urusan jenazah, karangan Syeh Salim bin Syeih Samir Hadhri (ditulis horizontal), dan terjemahan bahasa Madura dengan Arab Pegon (ditulis diagonal) oleh Ustadz Umar

Faruq, ulama Bangkalan, Madura. Pelafalan terjemahan Madura dari tulisan Arab Pegon tersebut: 1) kaangghuy (bahasa Indonesia: untuk), 2) adua' (berdoa), 3) paneka (tersebut), 4) mendem mayyit (menguburkan mayat), 5) paling sakone'na (paling sedikitnya).

Sumber: Kontribusi Mas'udi Eko Diansyah, S.Pd.I, 2015
Secara teknikal, tulisan Arab Pegon di kitab kuning adalah hasil dari goresan tangan (handwriting) santri sehingga karakter estetik desain huruf tergantung pada skill masingmasing santri sebagai "desainer" dalam menuliskannya. Aspek estetik huruf dilihat dari karakter goresan yang luwes dan dinamis. Lantara secara anatomis, stroke atau tubuh huruf Hijaiyah didominasi karakter garis melengkung (curve stroke), mirip seperti bowl (stroke melengkung) pada huruf latin, atau spine (tulang punggung yang melengkung pada huruf "S") pada huruf Latin. Serta ditulis bersambung sebagaimana huruf Arab lazimnya menyerupai penulisan huruf Latin jenis script (tulisan dengan huruf latin bersambung), sehingga menurut Hisyam (2006: 490-498), Arab Pegon dalam istilah Inggris disebut Pegon Script.

Penjelasan isi kitab dengan huruf Arab Pegon tersebut, ditulis di bawah atau di samping redaksi aslinya. Penataan yang demikian memberikan tata artistik yang khas. Beberapa kitab kuning umumnya disajikan dengan layout yang khusus dengan blank space atau kolom kosong untuk fitur komentar, penjelasan, maupun keterangan yang dituliskan dengan Arab Pegon. Sehingga antara rupa huruf redaksi tulisan asli (huruf Hijaiyah) dan rupa huruf Arab Pegon nampak satu kesatuan (unity) meski berbeda bahasa. 


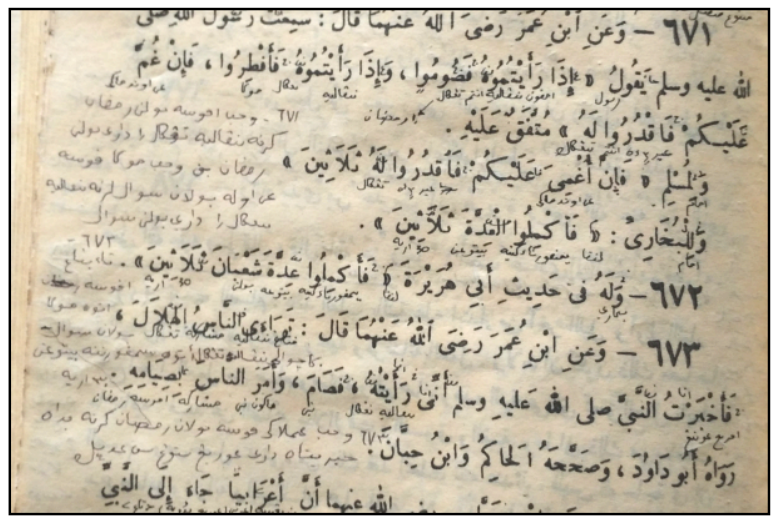

Gambar 3 Potongan tulisan berbahasa Arab pada kitab kuning Bulughul Maram yang dikarang oleh $\mathrm{Al}$ Hafdz Ibnu Hajar Al Asqalani, beserta goresan keterangan berbahasa Madura yang ditulis dalam Arab Pegon. Kitab ini berisi tuntunan ibadah.

Sumber: Kontribusi Mas'udi Eko Diansyah, S.Pd.I, 2015

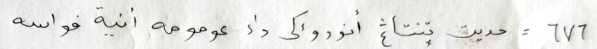

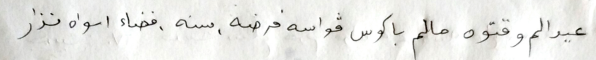

Gambar 4 Salinan tulisan tangan hasil terjemah dan keterangan dalam bahasa Madura dari kitab kuning Bulughul Maram pasal 677, jika ditulis dalam huruf Latin: "Hadits tentang anodhuwaghi da' omomma aniat pasa e dalem bakto malem, bagus pasa fardhu, sonnat, otaba nadzar" (artinya: Hadits tentang tuntunan umum niat berpuasa di malam hari, baik puasa wajib, sunnah, maupun nadzar/janji)

Sumber: Kontribusi Mas'udi Eko Diansyah, S.Pd.I, 2015

Dalam konteks kebudayaan, mengamati fenomena homogenitas rupa huruf ini (samasama huruf Hijaiyah, baik huruf Arab maupun Arab pegon), menurut penulis, sebagai simbol kebudayaan Islam, praktik tipografi Arab Pegon pada penulisan kitab kuning yang demikian mengisyaratkan seolah-olah menjadi perangkat "benteng pertahanan" yang mendua (seperti dialektika dua kutub).
Pertama, benteng pertahanan (mempertahankan) tradisi keislaman, baik itu agar fasih menulis huruf Arab, atau mempertahankan unity atau keseragaman tulisan (rupa huruf) kitab itu sendiri. Kedua, tradisi tulis Arab Pegon justru menjadi benteng (atau dibentengi?) sebagai upaya agar "tidak tersentuh" oleh kebudayaan lain (misal kebudayaan Barat/Eropa dengan instrumen kebudayaannya berupa huruf Latin) karena alasan mempertahankan tradisi salaf terdahulu.

\section{Arab Pegon sebagai instrumen tulis pasaran}

Dalam terminologi Madura, santri disebut santrè (baca: santreh), dan orang yang menamatkan pendidikan di ponpes disebut "bhindârâ" (baca: bhindhereh) yang diperlakukan seperti kèyaè (baca: kiyaeh) atau kiyai (pemuka agama Islam) namun tidak setingkat atau lebih tinggi dari kiyai. Pondok atau "pondhuk" (bahasa Madura) atau lengkapnya pondok pesantren (ponpes) yang dimaksud yaitu merujuk pada tempat santri atau murid-murid belajar dan mendalami agama Islam, biasanya menjadi tempat bermukim (mondok) santri-santri tersebut. Tidak jarang pesantren dahulunya hanya terbentuk dari langghâr (baca: langgher, atau langgar dalam bahasa Jawa) yaitu tempat pengajian anak-anak belajar Al-quran dan 
pelbagai ilmu agama Islam yang umumnya diasuh kiyai. Misalnya PP Sumber Anyar AzZubair Pamekasan tempat Panembahan Ranggasukawati, Raja Pamekasan yang pertama, PP Nurul Hikmah di Pamekasan yang didirikan semasa pemerintahan Panembahan Ranggasukawati, dan masih banyak yang lain (Pemkab Pamekasan dan FIB UGM, 2010: 279).

Keberadaan pesantren pun sesungguhnya mengindikasikan bentukbentuk pemribumian teologi (upaya peresapan Islam dalam masyarakat) yang ditempuh penyiar Islam dengan mendirikan lembaga pendidikan memakai metode pengajaran (kebudayaan) Islam (sebagai kebudayaan asing) yang disesuaikan dengan keperibadian lokal pribumi. Pendidikan dan pengajaran Islam merupakan jantung kehidupan dan eksistensi pesantren. Kegiatan mencerdaskan pribumi dalam wadah pesantren kemudian menjadi ciri pendidikan Nusantara yang khas.

Hingga saat ini, ponpes tradisional/salaf maupun modern di Madura jumlahnya menjamur. Berdasarkan laman Wiki Aswaja yang dikelola Persaudaraan Profesional Muslim Aswaja (PPMA), organisasi afiliasi organisasi islam Nahdlatul Ulama (NU), yang merilis daftar pesantren di Madura beserta alamat lengkap, diketahui sekitar 258 ponpes tersebar di kabupaten Sumenep (http:// moslemwiki.com/

Pesantren_di_Kota_Sumenep), 278 ponpes di kabupaten Pamekasan (http://moslemwiki .com/Pesantren_di_Kota_Pamekasan), 159 ponpes di kabupaten Sampang (Error! Hyperlink reference not valid. Pesantren_di_Kota_Sampang), dan 179 ponpes di kabupaten Bangkalan (http://moslemwiki.com/Pesantren_di_Kota_ Bangkalan). Lulusan pesantren Madura yang tersebar di berbagai penjuru, tidak jarang tercatat menjadi aktor dalam sejarah perkembangan Islam di Nusantara.

Keadaan sosial budaya masyarakat Madura menentukan dalam diaspora dan penggunaan huruf Arab Pegon. Budaya pesantren, bhindârâ, dan kiyai mengindikasikan perkembangan ilmu pengetahuan dan kebudayaan Islam di tengahtengah masyarakat Madura yang kemudian mewarnai corak masyarakat dan tersublimasi menjadi kebudayaannya. Tidak hanya di pesantren, bhindârâ dan kiyai di tengahtengah masyarakat sejak dahulu dapat dimungkinkan memberikan peran penting dalam diaspora dan perkembangan penggunaan huruf Arab (asli) maupun Arab Pegon di tengah-tengah masyarakat etnik Madura. Hal ini didasarkan pada peran orang dengan status sosial tersebut umumnya 
sebagai ghuru (baca: ghuruh) atau guru yang memberikan pendidikan agama di tengahtengah masyarakat. Apalagi pola lapisan sosial masyarakat Madura yang menempatkan bhindârâ dan kiyai sebagai tokoh yang disegani dan "berkedudukan" tinggi.

Bahkan kristalisasi nilai-nilai lokal tersebut dikukuhkan dalam ungkapan tradisional Madura yang senantiasa ditanamkan sejak dahulu (termasuk pada penulis), yaitu: bhuppa', babu, ghuru, rato, (secara berurutan artinya: ibu, bapak, guru, raja/pemerintah). Ungkapan tersebut bermakna hierarki kepatuhan terhadap "figur" dalam masyarakat etnik Madura umumnya. Dalam konteks tersebut, kiyai dan bhindârâ yang umumnya sebagai figur guru masyarakat Madura, didudukkan dalam posisi yang mendapatkan penghormatan ("bahkan dikultuskan") setelah ibu dan ayah. Apalagi jika figur kiyai dan bhindârâ tersebut memiliki darah bangsawan atau garis keturunan keluarga kraton/kerajaan di Madura.

Dipandang dari perspektif kulturalhistoris, bisa dikatakan hal itu merupakan dampak pergeseran dan memudarnya tata nilai dan budaya dari pengaruh feodalisme masyarakat yang berpusat pada raja-raja atau bangsawan kraton, yang kemudian lebih berorientasi pada agama Islam, yaitu kiyai sebagai tokoh sentralnya. Mengamati pola relasi tersebut, penulis menduga, melalui pengajaran Islam oleh kiyai di tengah-tengah masyarakat luas yang demikian, sejak dahulu memberikan andil dalam pendistribusian dan penggunaan huruf Arab Pegon menjadi huruf pasaran atau instrumen baca tulis keseharian, khususnya dalam bahasa Madura.

Sebagaimana yang penulis dapati dewasa ini, bahwa generasi lawas atau kaum tua (5060-an tahun) terutama di desa-desa Madura, fasih membaca tulis Arab Pegon daripada huruf Latin. Misalnya keluarga Mukhlis (21 tahun), warga yang pernah penulis kunjungi di desa Proppo, Pamekasan, hari ketujuh pasca Idul Fitri 2015. Mukhlis mengaku bahwa dirinya, ibu (60-an tahun), dan bibinya belajar Arab Pegon dari Ma' Kaèh (baca: Mak Kaeh, artinya kiyai lokal) pengajar madrasah, langgar atau surau-surau tempat mengaji Alquran di desanya.

Sudah menjadi hal umum di Madura sejak dahulu, pendidikan agama lebih diutamakan meskipun tidak dalam nuansa pendidikan formal. Bahkan anak kecil jenjang taman kanak-kanak sudah diserahkan kepada guru ngaji untuk belajar agama, adapula anjuran lebih baik melanjutkan studi ke ponpes daripada sekolah umum. Di Proppo sendiri saat ini sudah tersebar 40 -an lebih ponpes (http://moslemwiki.com/ Pesantren_di_Kota_Pamekasan), lain pula 
tempat-tempat ngaji di surau-surau, langgar, maupun masjid. Bahkan menurut Mukhlis, Ibu dan Bibi Mukhlis tidak pandai baca tulis huruf Latin, namun terbiasa menulis Arab Pegon bahasa Madura. Bahkan keduanya tidak bisa dan tidak mengerti berkomunikasi dalam bahasa Indonesia, sehingga komunikasi yang dipakai adalah bahasa Madura ketika ditemui penulis. Dahulu ketika komunikasi tak semudah sekarang, keluarga Mukhlis yang sedang berpisah jarak, seringkali saling menulis surat dengan huruf Pegon bahasa Madura.

Melihat realitas yang terjadi pada contoh masyarakat Madura tersebut, tentunya merupakan hasil pendidikan (keberaksaraan) di masa lampau. Dengan demikian, diaspora huruf Arab Pegon bahasa Madura juga tumbuh dan berkembang menjadi huruf pasaran terutama bagi golongan "masyarakat bawah" atau orèng kènè' (baca: oreng kenik) sebagai hasil transmisi pengajaran dari golongan intelektual (bhindârâ dan kiyai). Karena besar kemungkinan bahasa Madura adalah bahasa Ibu yang hanya dimengerti dan dibiasakan masyarakat untuk belajar memahami dunia dan lingkungan sekitarnya. Mengingat beberapa orang desa di Madura terlebih para kaum tua yang penulis ketahui dewasa ini, masih tidak mengerti selain bahasa
Madura, misalnya bahasa Jawa bahkan bahasa Indonesia sekalipun.

Bisa jadi, hal tersebut juga karena akses pendidikan (khususnya keberaksaraan) masyarakat bawah tidak segemilang, tidak sevariatif, atau bahkan tidak semudah yang didapatkan golongan atas, selain karena masyarakat lebih mengenal huruf Arab terlebih dahulu daripada huruf Latin. Mengingat hingga tahun 90-an, pendidikan umum di Madura masih menjadi barang mewah. Apalagi jika dibandingkan dengan masa yang lebih lampau. Seperti halnya Sartono Kartodirdjo dalam Soekiman (2011: 12) menempatkan "orang kecil" di urutan terbawah daripada golongan Indo dan Belanda, priyayi, elite birokrasi Eropa maupun Indo, di antara masyarakat Hindia Belanda. Sebagai contoh dapat dilihat pengalaman golongan atas Madura, seperti kegemilangan pendidikan (keberaksaraan) Pangeran Abdurrachman Pakunataningrat atau sering dikenal Sultan Sumenep (Penguasa Sumenep pada 1811-1854) yang dapat menguasai bahasa Madura, Jawa, Kawi, Sansekerta, Melayu, Belanda, Inggris, dan bahasa Arab. Bahkan Sultan mendapat gelar Doktor kehormatan dalam kesusasteraan dari pemerintah Inggris karena membantu Letnan Gubernur Jenderal Sir Thomas Stamfford Raffles dalam menerjemahkan salah satu prasasti Sansekerta 
sebagai data penulisan buku History of Java (Departemen Pendidikan dan Kebudayaan R.I., 1979: 110-111 dan Moelyono, 1984: 4748).

Pada perkembangan selanjutnya, dalam Pemkab Pamekasan dan FIB UGM (2010: 38), karena pengaruh konteks sosial masyarakat pada umumnya, yaitu lingkungan relijius yang sangat kental, menyebabkan terjadi peningkatan orang Madura yang naik haji atau studi di Timur Tengah pada abad XX. Kontak dan komunikasi dengan dunia Arab yang demikian, ditengarai pula membawa angin segar terhadap perkembangan intelektualitas masyarakat Pamekasan, yang berimbas pada tradisi tulis Arab Pegon.

Pada abad XX pula, perkembangan penulisan huruf Arab Pegon semakin terang benderang karena ditemukan bukti tertulis. Misalnya kitab Atmorogo berisi petunjuk dan ajaran budi pekerti, saling menghormati, dan bercorak sufi, yang ditengarai ajarannya mendapat pengaruh dari Jawa; kitab Nurbuat berisi cerita dan ajaran ketauladanan, doa-doa nurbuwat, dll; kitab Patmorogo yang berisi ajaran sufistik, diperkirakan sezaman dengan kitab Atmorogo, dan diduga terkait persebaran ajaran sufi dan tarekat di Madura; serta kitab Tantraningrat berisi cerita dan perjalanan hidup Nabi Muhammad SAW, serta suri tauladan dan ajaran tentang kemanusiaan.
Kitab-kitab tersebut tidak diketahui siapa penulisnya, namun menjadi koleksi salah seorang warga di Pamekasan (Pemkab Pamekasan dan FIB UGM, 2010: 178-179).

\section{Arab pegon dan isu tipografi dewasa ini}

Sebagaimana kebudayaan sebelumnya, yaitu sosialisasi dan penyebaran agama HinduBudha yang begitu kuatnya ditunjukkan melalui sisa-sisa peninggalan kebudayaan. Keberadaan huruf Arab Pegon juga mengindikasikan realitas budaya dan agama terakulturasi begitu berhasilnya dan menjadi salah satu indeks atau jejak kejayaan kebudayaan Islam di bumi Madura, yaitu huruf Arab Pegon. Maka sebagai produk dari akulturasi atau pertemuan dua kebudayaan, huruf Arab Pegon sebagai simbol pengaruh kerajaan Islam di Nusantara, dapat dikatakan merupakan hasil upaya dan siasat cerdik pemribumian teologi, "lokalisasi", atau kontekstualisasi kebudayaan Islam-Arab melalui tipografi. Keberhasilan perpaduan kebudayaan melalui huruf Arab Pegon, tidak hanya berdampak pada munculnya kesinambungan budaya dan agama, tapi juga berdampak pada munculnya kestabilan ideologi, politik, dan sosial, sebagaimana yang telah diurai sebelumnya.

Tipografi Arab Pegon pada dasarnya mempertemukan kode aksara dan kode bahasa 
lain untuk "dipinjam-pakai”. Huruf Arab Pegon sejatinya adalah hasil "jerih payah" dari upaya "mendamaikan" huruf dari kebudayaan yang semula dianggap asing (Arab-Islam) dengan kebudayaan lokal, yaitu bahasa lokal/pribumi (vernacular language). Bisa dibilang tujuh huruf baru sebagai simbol fonem hasil modifikasi tersebut semacam praktik apropriasi. Maksudnya, huruf Arab "yang asing” digubah, disesuaikan, dihasilkan produk beberapa simbol fonem baru kemudian dijadikan milik sendiri (kebudayaan lokal), karena tentunya deretan huruf gubahan tersebut tidak masuk daftar huruf Hijaiyah yang original.

Artinya proses akulturasi dalam konteks Arab Pegon, memungkinkan penyesuaian diri (adaptasi) kebudayaan Islam dalam kehidupan sosial untuk mendukung bahasa dan simbolsimbol komunikasi lokal dengan cara "damai", luwes, dan dapat diterima masyarakat luas. Hal ini menunjukkan sifat huruf Arab yang dinamis, mengacu pada konsep dinamika huruf yang ditulis Sanusi (2010: 61), bahwa "sifat aksara/huruf sebagai indeks dari kebudayaan yang selalu dinamis atau menyesuaikan dengan warna kebudayaan lokal tempat di mana huruf itu hidup". Awalnya huruf Arab digunakan di Nusantara sebagai bagian dari kebudayaan Islam-Arab (original), kemudian mengalami "pergeseran" atau dinamika kebudayaan hingga muncul variasi huruf Arab untuk penulisan bahasa lokal, yaitu Arab Pegon.

Berpijak dari pengertian bahasa menurut Koentjaraningrat (2009: 261) sebagai sistem perlambangan manusia yang lisan maupun tertulis untuk berkomunikasi satu dengan yang lain. Maka sebagai instrumen bahasa khususnya dalam konteks Madura, huruf Arab Pegon didesain sebagai sistem perlambangan untuk menjembatani komunikasi dan transfer/pertukaran kebudayaan Islam, Arab, dan Madura. Visualitas dan rupa huruf Arab Pegon sekaligus menjadi bahasa universal yang saling bisa dipahami.

Sebagaimana telah disebutkan di awal tulisan ini, bahwa huruf Arab Pegon berkembang disinyalir karena adanya kesulitan menerjemahkan kata-kata dan konsep-konsep Islam dan Arab secara spesifik ke dalam bahasa lokal, akhirnya bunyi/fonem asli dari bahasa diadopsi dan ditulis dengan Arab Pegon. Begitu juga dari segi universalitas dan familiaritas bahasa rupa (desain) huruf Arab Pegon dalam komunikasi, melalui pendidikan keberaksaraan, masyarakat Madura dapat membaca tulisan Arab Pegon, sementara orang atau ulama Islam daerah lain yang berinteraksi di Madura dapat mengerti pelafalan/pengucapan fonem bahasa Madura 
melalui tulisan Arab yang sudah familiar baginya, meski sudah dimodifikasi menjadi huruf Arab Pegon, sehingga tercapai maksud yang dikomunikasikan.

Uniknya, selain akomodatif untuk kata serapan dalam bahasa Arab, huruf Arab Pegon bisa dianggap lebih akomodatif untuk menuliskan kata-kata dengan punctuation mark atau tanda baca "bisat" dalam beberapa kata dalam bahasa Madura, daripada menggunakan huruf latin untuk menuliskan kata-kata dengan tanda bisat. Istilah tanda baca bisat merujuk pada tanda baca dalam bahasa Madura yang digunakan untuk memberikan bunyi konsonan " $k$ " (sama halnya bunyi " $k$ " di dalam bahasa Indonesia), namun seperti pelafalan bunyi " $k$ " pada kata "tidak"; bukan seperti pelafalan pada kata "skak"; "produk"; "makhluk", dan lain-lain. Tanda bisat dilafalkan mengikuti bunyi vokal dari suku kata sebelum tanda bisat dibubuhkan. Sebagai contoh: kata lonca' dibaca loncak (dalam bahasa Indonesia: "loncat/lompat"); sakè dibaca sakek (dalam bahasa Indonesia: "sakit"); atau sakonèna dibaca sakoneknah, (dalam bahasa Indonesia: “sedikitnya”). Dalam Arab Pegon, tanda bisat diwujudkan dalam satu karakter huruf Hijaiyah yang disebut hamzah ( $\&$ ) (lihat gambar 5) atau beberapa kata khusus memakai huruf 'ain ( ( ) (lihat gambar 6), sedangkan dalam kelompok huruf Latin, tanda bisat dituliskan dengan satu karakter tanda baca, yaitu tanda petik/kutip satu (`).

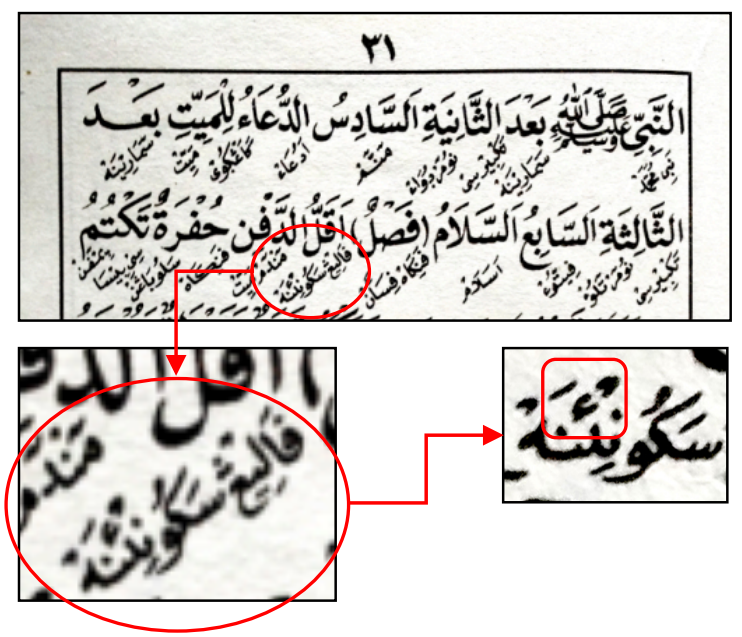

Gambar 5 Kata sakone'na (baca: sakonekna) (kanan bawah) ditulis dalam Arab Pegon. Tanda bisat diakomodasi dengan huruf Hijaiyah hamzah Sumber: Kontribusi Mas'udi Eko Diansyah, S.Pd.I, 2015

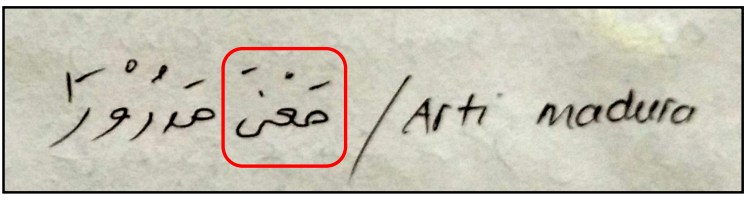

Gambar 6 Kata ma'na (baca: makna) (kanan bawah) ditulis dalam Arab Pegon. Tanda bisat diakomodasi dengan huruf Hijaiyah 'ain

Sumber: Kontribusi Mas'udi Eko Diansyah, S.Pd.I, 2015

Dari perspektif tipografi, pada kasus di atas, perwujudan satu karakter huruf dalam huruf Arab Pegon bisa dianggap lebih legible (mudah dikenal; terbaca jelas) daripada perwujudan satu karakter tanda baca, atau faktor lain: seperti bisa terlewatkan jika mata tidak teliti. Tentu saja, hal itu berlaku bagi siapa saja yang dapat membaca huruf Arab, 
sementara kata dalam huruf latin format bahasa Madura yang dituliskan dengan tanda bisat, belum tentu dibaca/dilafalkan dengan bunyi yang dikehendaki. Artinya, pengalaman visual terhadap huruf berpengaruh pada familiaritas. Sebagai ilustrasi, kata "makna" dalam bahasa Madura ditulis ma'na (baca: makna), dalam huruf Arab Pegon ditulis atau مَعْنَ (lihat gambar 6), atau kata sakonèna (baca: sakoneknah), dalam huruf Arab Pegon سكَوْنِنَنَه atau (dalam bahasa Indonesia: "sedikitnya"). Jika orang tidak familiar dengan bahasa Madura, maka kata ma'na akan dibaca "mana" saja, begitu pula kata sakonèna akan dibaca sakonena. Sementara, orang yang tidak mengerti bahasa Madura namun dapat membaca huruf Arab, dengan bantuan tulisan Arab Pegon dimungkinkan dapat membaca kata-kata dalam bahasa Madura dengan benar. Hal inilah menurut penulis, keunggulan tipografi Arab Pegon dalam mengakomodasi karakter huruf untuk legibilitas penulisan tanda bisat untuk kata dalam bahasa Madura.

Praktik-praktik tipografi Arab Pegon dewasa ini, dapat dikatakan mengalami pergeseran budaya. Sebagaimana dijelaskan sebelumnya, praktik Arab Pegon bergulir sebagai alat sebar dan transmisi pengetahuan Islam, selanjutnya berlangsung sebagai instrumen pendidikan (keberaksaraan) Islam di lingkungan masyarakat santri, kemudian juga berubah luas cakupannya dalam praktik untuk komunikasi pasar. Namun, di era huruf Latin ini, Arab Pegon dapat dikatakan "mati suri" jika bukan berada di "lingkungan hidupnya" dan cenderung tergantikan dengan huruf Latin yang menguasai praktik-praktik tipografi dunia. Dalam konteks kebudayaan, budaya Arab di Madura "luntur" dari sisi tipografis, tergantikan dengan kebudayaan modern yang diusung tipografi huruf Latin.

Tipografi dewasa ini seringkali diidentikkan dengan huruf huruf Latin karena kuasa dan dominasinya dalam diaspora informasi, komunikasi, serta seni dan desain. Padahal tipografi tidak melulu tentang huruf Latin, tetapi meliputi semua jenis huruf yang ada. Di samping itu, huruf Latin seringkali diasosiasikan dengan kebudayaan Barat/Eropa. Mengingat secara historis, cikal bakal huruf Latin yang dipakai hingga kini dipercaya berasal dari Barat, yang dirintis oleh bangsa Romawi. Sebagaimana yang dikenal sekarang, bangsa Romawi menulis angka dengan simbol dari huruf kapital mereka, seperti huruf "I”, “V”, “X”, “L”, “C”, “D”, dan "M" (Sihombing, 2003: 46). Salah satu kontribusi orang Romawi pada masa sistem tulisan awal adalah penciptaan bentuk karakter huruf Trajan Column berangka tahun $114 \mathrm{M}$ sebagai salah satu huruf yang paling 
terkenal dan terbaik mencirikan identitas Romawi, dengan karakter klasik, elegan, kombinasi yang seimbang dari bentuk, proporsi, dan kesederhanaan, yang menginspirasi desainer huruf di seluruh dunia (Strizver, 2006: 17). Karena itulah huruf Latin sering disebut huruf Roman atau huruf "milik orang Roma” (roman letterform).

Begitu pula di Indonesia, perkembangan dan diaspora huruf Latin tidak terlepas dari praktik kolonialisme dan tentunya disatupaketkan dengan kebudayaan Barat yang dibawa atau kerja pembaratan yang dijalankan. Kolonialisme yang paling masif adalah yang dipraktikan Belanda di Nusantara sejak abad XVI. Sebelum itu, sejak lama bangsa asing seperti India, Cina, Arab, dan Portugis telah hadir di Pulau Jawa (Soekiman, 2011: 1). Artinya, bersamaan dengan perkembangan Belanda di Nusantara, bisa dikatakan huruf Latin di Indonesia berkembang belakangan, tetapi kini menjadi paling banyak dan sering digunakan.

Dewasa ini, Surat kabar dan media massa lainnya baik yang terdistribusi di Madura atau Indonesia ramai-ramai menggunakan huruf Latin. Hal ini karena bahasa Indonesia sebagai bahasa nasional dilegitimasikan, diasosiasikan, dan diidentikkan dengan tulisan huruf Latin (bukan aksara lokal atau Arab Pegon).
Apalagi di era digital ini, baik teknologi informasi dan internet kian mendukung persebaran huruf. Setiap orang dengan mudahnya mengakses dan memakai beragam variasi font digital. Selain itu, penyedia informasi di internet pun demikan, menyajikan pelbagai informasi melalui beragam tipografi huruf Latin, baik yang bertujuan untuk komunikasi maupun menyangkut aspek estetik huruf. Kesadaran akan pentingnya huruf digital kemudian menciptakan upaya kesinambungan dalam penciptaan desain huruf-huruf digital, baik Latin maupun huruf lain.

Beralih kembali ke huruf Arab Pegon, bahkan di lingkungan "hidupnya sendiri", misalnya lembaga pendidikan Islam bercorak seperti madrasah, umumnya hanya memiliki jatah minim proses belajar mengajar dengan huruf Arab Pegon. Madrasah sendiri lebih dominan menggunakan huruf Latin dalam proses pembelajaran. Hal ini sebagaimana diungkapkan oleh seorang informan Mas'udi Eko Diansyah, seorang ustadz atau pengajar di Madrasah Tsanawiyah Al-Amien Branta Pesisir, Pamekasan, Madura, bahwa proses pembelajaran dengan huruf Arap Pegon pada saat tertentu saja, misalnya pada pembelajaran bahasa Arab, Tajwid (tata aturan dan metode membaca Alquran), dan lain-lain, serta tidak selalu menggunakan bahasa Indonesia, 
mengingat lembaga tersebut mengikuti kurikulum pusat (Departemen Agama).

Menurut Hisyam (2006: 497), adanya madrasah dianggap sebagai perkembangan sistem pendidikan Islam yang modern, sehingga corak metode pembelajarannya mengadopsi Barat dan huruf Latin. Hal ini terjadi sejak abad XX. Istilah"madrasah" (bahasa Arab) yang merujuk sekolah atau perguruan Islam. Di dalam perkembangannya, ponpes secara administratif umumnya memiliki lembaga pendidikan formal berupa madrasah atau bersifat madrasiyah, misalnya jenjang Madrasah Diniyah/MD (setara Pendidikan Usia Dini/PAUD), Madrasah Ibtidaiyah/MI (setara Sekolah Dasar/SD), Madrasah Tsanawiyah/MTs (setara Sekolah Menengah Pertama/SMP), Madrasah Aliyah /MA (setara Sekolah Menengah Atas/SMA), hingga perguruan tinggi. Pesantren tradisional yang tidak memiliki kurikulum madrasiyah pendidikan formal juga masih ada, sehingga menghendaki santri yang juga ingin menjalani pendidikan formal untuk sekolah di lembaga lain. Begitu juga, pada perkembangannya madrasah berdiri sebagai lembaga pendidikan mandiri yang tidak memungkinkan muridmurid atau santri bermukim, baik dengan kurikulum formal maupun nonformal.

Namun, di lingkungan pesantren tradisional, praktik tipografi Arab Pegon masih berlangsung. Artinya huruf Arab Pegon kini hanya menjadi instrumen literasi pendidikan yang terbatas ruang lingkupnya, bukan instrumen komunikasi pasar secara luas. Artinya, secara sendirinya tradisi literasi dan kepustakaan oleh masyarakat santri di dalam lingkungan pesantren menjadi penjaga eksistensi keberlangsungan huruf Arab Pegon.

Untuk menelusuri praktik tipografi ini di luar pesantren, informasi dari informan alumni pesantren sangat penting. Menurut Nasiruddin, pasca lama lulus dari pesantren, ia jarang menulis Arab Pegon dalam keseharian, karena sudah tergantikan dan terbiasakan menggunakan huruf Latin. Begitu juga Mukhlis, menulis dengan huruf Arab Pegon hanya dipakai jika terdapat keperluan tertentu saja, misalnya untuk memberikan informasi kepada orangtuanya yang tidak mengerti huruf Latin. Sementara menurut Masudi, dirinya masih tetap mengkaji kitab-kitab dan komentar dengan huruf Arab Pegon terutama untuk kepentingan pendalaman materi dan pengajaran terkait ilmu seputar Islam kepada masyarakat dan di sekolah tempat ia mengajar. Selain itu membaca dan menulis huruf Arab Pegon untuk menuliskan materi ceramah dan khutbah untuk pengajian Islam.

Senada dengan Masudi, penulis juga sering mendapati do'a-doa berbahasa Madura untuk orang meninggal yang dibaca ustadz 
atau kiyai atau tokoh masyarakat seringkali dituliskan dalam huruf Arab Pegon berbahasa Madura, yang kemudian diteruskan dari pelbagai do’a bahasa Arab. Hal ini acapkali ditemui ketika mengantarkan jenazah ke kubur. Praktik ini juga seringkali dilakukan oleh kiyai ketika "dimintai” doa-doa tertentu untuk keperluan tertentu pula. Arab pegon juga seringkali digunakan untuk menuliskan nama-nama seseorang bercorak Nusantara, baik untuk doa-doa atau untuk goresan seni kaligrafi sebagai benda display di rumah. Dengan demikian, kini praktik Arab Pegon hanya "lestari" saat kondisi tertentu saja, khususnya dalam lingkungan pendidikan Islam dan keperluan ritual, tetapi jarang dipraktikan dalam komunikasi oleh masyarakat umum.

Melihat fenomena tersebut, jika boleh diidentifikasikan lewat dikotomi kelas, ia disamakan halnya sebagai bentuk resistensi dan perjuangan melawan penjajah tempo dahulu. Huruf Arab Pegon sebagai manifestasi kebudayaan Islam yang telah lama menjadi milik lokal juga sedang dalam pergulatan (pertarungan instrumen visual bahasa) mengimbangi kuasa huruf global yang dibawa rezim kolonial, yaitu huruf Latin. Apalagi saat ini huruf Latin kian dikukuhkan sebagai aksara yang lazim dipakai dalam praktik- praktik resmi di lingkungan pemerintahan, baik di Madura maupun di Indonesia.

Sanusi (2006: 76-77) melihat gejala huruf Latin yang mengglobal melalui berbagai asumsi terhadap sikap intelektual pribumi atas penerimaan huruf Latin, sebagai berikut: pertama, sikap rela menerima huruf Latin sebagai huruf masa depan dan modern, apalagi jika dikaitkan karir pendidikan intelektual pribumi tidak terlepas pendidikan yang ditransmisikan melalui huruf Latin; kedua, kalangan pengguna huruf Latin dianggap sebagai golongan cerdik pandai yang telah mencoba mengimbangi dominasi huruf Latin, namun kalah dukungan dari segi budaya dan politik, serta dianggap lebih mumpuni dalam perguliran wacana, ketimbang masyarakat daerah yang hanya bisa dan membaca huruf lokal atau yang telah dibiasakan. Selain itu, menurut penulis, sebab lainnya adalah penerimaan akibat tidak ada pilihan lain dan penetrasi yang terlalu masif, sebagai upaya menyesuaikan kondisi lingkungan dan gairah zaman. Sehingga jika tidak melazimkan penggunaan huruf Latin, masyarakat dalam suatu kebudayaan tidak bisa berkembang sesuai dengan keadaan global. Huruf Latin disamakan sebagai patokan "kurs" yang diterima sebagian besar pihak, apalagi perkembangannya didukung media digital. 
Memang tidak bisa dipungkiri bahwa penggunaan, distribusi, serta pelestarian huruf, khususnya huruf Arab Pegon, tidak terlepas dari berbagai faktor sosial budaya yang melingkupinya. Nasib "hidup" dan eksistensi huruf berkaitan dengan kecenderungan pola dan sikap masyarakat untuk melestarikan dan mengenalkannya kepada kebudayaan lain yang ada. Sebab upaya yang demikian sangat menentukan kelestarian bersama kebudayaan yang diwakilinya atau justru tersingkir di tengah dinamika kebudayaan.

Praktik ini sejalan dengan konsep globalisasi yang menghendaki kontestasi global antar huruf melalui berbagai medium pendukung, yaitu melalui perpustakaan, surat kabar, dan media digital. Keberhasilan penetrasi yang kemudian mendominasi dunia global melalui relasi pelbagai medium tersebut, menyebabkan (bahasa visual) huruf dapat menembus sekat-sekat budaya, ruang dan waktu, sebagaimana dicontohkan pada huruf Latin yang juga dilibatkan termasuk dalam praktik pendidikan Islam.

Dari sini penulis melihat, ada semacam upaya bahwa huruf Latin sekaligus dijadikan sebagai perangkat kesempatan untuk mengakses kebudayaan di mana saja, di masa kini dan depan. Dipersonifikasikan sebagai makhluk hidup, huruf Latin dianggap mampu beradaptasi di habitat mana pun dan cenderung mendominasi kontestasi dalam dinamika kebudayaan. Dibandingkan dengan huruf Arab Pegon yang kini tersisih di sudut lingkungan sosial budaya tertentu dan "telah gagal" kembali bermain di kancah global, setelah sekian lama berperan penting dalam peradaban dan kebudayaan Madura.

\section{KESIMPULAN}

Huruf Arab Pegon khususnya yang dipakai untuk menuliskan dalam bahasa Madura, merupakan produk akulturasi dari kebudayaan Islam-Arab, Jawa, dan Madura (dari segi struktur penggunaan bahasa). Huruf Arab Pegon sejatinya adalah hasil "jerih payah" dari upaya "mendamaikan" huruf dari kebudayaan yang semula dianggap asing (Arab-Islam) dengan kebudayaan lokal, yaitu bahasa lokal/pribumi (vernacular language). Kini, praktik-praktik tipografi Arab Pegon dapat dikatakan mengalami pergeseran budaya. Praktik Arab Pegon mula-mula diduga bergulir sebagai alat sebar dan transmisi pengetahuan Islam, selanjutnya berlangsung sebagai instrumen pendidikan (keberaksaraan) Islam di lingkungan masyarakat santri, kemudian juga berubah luas cakupannya dalam praktik untuk komunikasi pasar. Namun, di era huruf Latin ini, huruf Arab Pegon dapat dikatakan tersisih di sudut lingkungan sosial budaya tertentu dan 
telah gagal kembali bermain di kancah global, dan cenderung tergantikan dengan huruf Latin yang menguasai praktik-praktik tipografi dunia.

\section{DAFTAR INFORMAN}

1. Mas'udi Eko Diansyah, S.Pd.I, seorang ustadz atau pengajar di Madrasah Tsanawiyah Al-Amien Branta Pesisir, Pamekasan, Madura. Ia memperoleh Sarjana Pendidikan Islam di Sekolah Tinggi Agama Islam Negeri (STAIN) Pamekasan, serta alumni Pondok Pesantren Miftahul Ulum Banyu Putih Kidul Lumajang (bercorak Madura), Jawa Timur. Ia bertempat tinggal di Desa Branta Pesisir, kecamatan Tlanakan, kabupaten Pamekasan, Madura.

2. Mukhlis, aktif mengajar mengaji Alquran, asal Desa Proppo, Pamekasan, Madura. Pernah belajar baca tulis Arab Pegon untuk kajian kitab kuning selama menempuh pendidikan Madrasah Ibtidaiyah di desanya. Sekarang menjadi abdi negara di kantor keuangan negara daerah Papua.

3. Nashiruddin, alumni Universitas Islam Negeri (UIN) Surabaya, asal Desa Larangan Tokol, Pamekasan, Madura. Pernah belajar baca tulis Arab Pegon untuk kajian kitab kuning selama di Madrasah Ibtidaiyah dan menjadi santri nyulog atau santri tidak bermukim di Pondok Pesantren Az-Zubair Sumber Anyar, Tlanakan, Pamekasan.

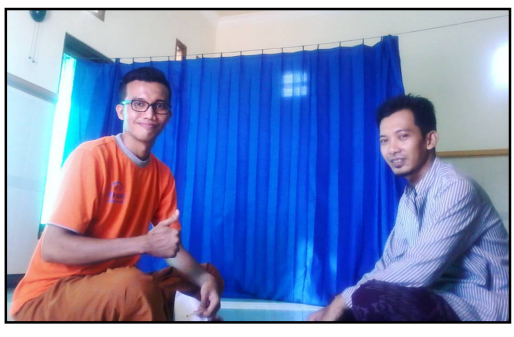

Gambar 7 Peneliti (kiri) dan Narasumber (kanan) Sumber: Naufan Noordyanto, 2016

\section{DAFTAR PUSTAKA}

[1] Abdurrachman. 1971. Sejarah Madura Selayang Pandang. Sumenep

[2] Bouvier, Hélène. 2002. Lèbur: Seni Musik dan Pertunjukan dalam Masyarakat Madura. Jakarta: Forum Jakarta-Paris, École française d'Extrême-Orient, Yayasan Asosiasi Tradisi Lisan, Yayasan Obor Indonesia

[3] Departemen Pendidikan dan Kebudayaan RI. 1979. Madura III: Kumpulan Makalah-Makalah Seminar 1979, Proyek Penelitian Madura dalam Rangka Kerja Sama Indonesia-Belanda untuk Pengembangan Studi Indonesia 1979. Jakarta: Departemen Pendidikan dan Kebudayaan R.I

[4] Fashri, Fauzi. 2014. Pierre Bourdieu: Menyingkap Kuasa Simbol. Yogyakarta: Jalasutra.

[5] Festschrift, R.P. Soejono. Simanjuntak. Hisyam, M. Prasetyo, Bagyo. Nastiti, Titi Surti (Ed). 2006. Archaelogy: Indonesian Perspective. Jakarta: LIPI Press

[6] Harris, David. 1995. The Art of Calligraphy. London: Dorling Kindersley Book

[7] Koentjaraningrat. 2009. Pengantar Ilmu Antropologi. Jakarta: Rineka Cipta

[8] Kuntowijoyo. 2002. Perubahan Sosial Masyarakat Agraris Madura. Yogyakarta: Matabangsa

[9] Melalatoa, M. Junus. 1995. Ensiklopedi Suku Bangsa di Indonesia. Jilid L-Z, Bab 
Madura, hal. 493-498. Departemen Pendidikan dan Kebudayaan RI

[10] Misrawi, Zuhairi. 2009. Kota Suci, Kekuasaan, dan Teladan Ibrahim. Jakarta: PT. Kompas Media Nusantara

[11] Moelyono, dkk. 1984. Mengenal Sekelumit kebudayaan Orang Madura di Sumenep. Yogyakarta: Departemen Pendidikan dan Kebudayaan, Direktorat Jenderal Kebudayaan, Balai Kajian Sejarah dan Nilai Tradisional Yogyakarta.

[12] Nadjib, Emha Ainun. 2007. Folklore Madura. Yogyakarta: Progress

[13] Pemerintah Kabupaten (Pemkab) Pamekasan dan Fakultas Ilmu Budaya Universitas Gadjah Mada (FIB UGM) Yogyakarta. 2010. Ensiklopedi Pamekasan: Alam, Masyarakat, dan Budaya. Yogyakarta: PT. Intan Sejati, Klaten

[14] Ricoeur, Paul. 2012. Teori Interpretasi. Yogyakarta: IRCiSoD

[15] Rustan, Surianto, S.Sn. 2011. Font \& Tipografi. Jakarta: PT. Gramedia Pustaka Utama.

[16] Setiono, Benny G. 2007. Tionghoa dalam Pusaran Politik. Jakarta

[17] Sihombing, Danton. 2003. Tipografi dalam Desain Grafis. Jakarta: Gramedia

[18] Soekiman, Djoko. 2011. Kebudayaan Indis: Dari Zaman Kompeni Sampai Revolusi. Depok: Komunitas Bambu

[19] Strizver, Ilene. 2006. Type rules!: The Designer's Guide To Professional Typograph. United States of America: John Wiley \& Sons, Inc.

[20] Werdisastra, Raden. Hadi, Moh. Toha (alih bahasa). 1996. Babad Sumenep. Pasuruan: PT. Garoeda Buana Indah

[21] Widiatmoko, FX., Sanusi, M., Lumenta, Hasti N., Sungatno. 2010. Aksara-Aksara Nusantara. Yogyakarta: ZAT Publishing

\section{Internet}

[1] Wiki Aswaja. Pesantren di Kota Bangkalan.

http://moslemwiki.com/Pesantren_di_K ota_Bangkalan. Diakses pada 10 Desember 2015, pukul 6.06 WIB

[2] Wiki Aswaja. Pesantren di Kota Pamekasan

http://moslemwiki.com/Pesantren_di_K ota_Pamekasan. Diakses pada 10 Desember 2015, pukul 6.05 WIB

[3] Wiki Aswaja. Pesantren di Kota Sampang. http://moslemwiki.com/Pesantren_di_K ota_Sampang. Diakses pada 10 Desember 2015, pukul 6.10 WIB

[4] Wiki Aswaja. Pesantren di Kota Sumenep. http://moslemwiki.com/Pesantren_di_K ota_Sumenep. Diakses pada 10 Desember 2015, pukul 6.08 WIB 